\title{
Meso-functionalized octamethoxyporphyrins: A new class of nonasubstituted porphyrins
}

\author{
PRADEEPTA K PANDA ${ }^{\mathrm{a}}$ and V KRISHNAN ${ }^{\mathrm{a}, \mathrm{b}, *}$ \\ a Department of Inorganic and Physical Chemistry, Indian Institute of Science, Bangalore 560 012, India \\ ${ }^{\mathrm{b}}$ Chemical Biology Unit, Jawaharlal Nehru Centre for Advanced Scientific Research, IISc Campus, \\ Bangalore 560 012, India \\ e-mail: vkrish@jncasr.ac.in
}

\begin{abstract}
Octamethoxyporphyrin containing multiple-donor substituents has been functionalized for the first time. A large number of its mono-meso-substituted derivatives with substituents such as nitro, amino, N-methylamino, formyl, hydroxymethyl, oxime, cyano and carboxy functional groups have been synthesized and characterized. They form a new class of nonasubstituted porphyrins. Crystallographic studies on the cyano derivative show that the $-\mathrm{CN}$ group is in conjugation with the prophyrin $\pi$-system. The calculated optical transition energies and the electron densities on the imino nitrogens of the synthesised porphyrins using AMI calculations correlate well with the experimentally observed data. Mesosubstituted porphyrins are found to be essentially planar.
\end{abstract}

Keywords. Octamethoxyporphyrin; meso-functionalization; nonasubstituted porphyrins; basicity; AM1 semi-empirical correlation.

\section{Introduction}

Porphyrins are an important class of biological pigments and they display remarkable properties that qualify them as advanced materials. ${ }^{1}$ The functions of the 22- $\pi$ electron porphyrin core can easily be altered with the nature of the central metal ion in the core and/ or by the presence of electron-withdrawing or -donating peripheral substituents. Among the various types of porphyrins, $\beta$-substituted porphyrins are unique owing to their close resemblance to naturally occurring porphyrins. Also, these porphyrins as well as their suitably substituted derivatives can be employed in designing multi-porphyrinic assemblies. For this it is essential to have an understanding of their reactivity at the meso-position that is influenced by both the electronic and steric nature of the substituents. Thus far, the studies involved have only been related to functionalization of aetioporphyrins ${ }^{2}$ and octaethylporphyrin, ${ }^{3}$ and this chemistry is little explored beyond the octaalkyporphyrins, owing to the difficulty in synthesizing suitable $\beta$-octasubstituted porphyrins. Therefore, the recently reported octamethoxyporphyrin, ${ }^{4}$ which carries multiple electron-donating substituents, drew our attention to explore their pro- perties further. The meso-functionalisation of octamethoxyporphyrin 1 with both electron-donor and -acceptor substituents provides a convenient route towards the synthesis of porphyrins that have potential applications in nonlinear optics. Here, we report the synthesis and characterization of a new class of nonasubstituted octamethoxyporphyrin bearing various meso substituents, viz. nitro, amino, N-methylamino, formyl, hydroxymethyl, oxime, cyano and carboxy functional groups.

\section{Experimental}

All the solvents used in this study were procured commercially, purified according to standard proce-

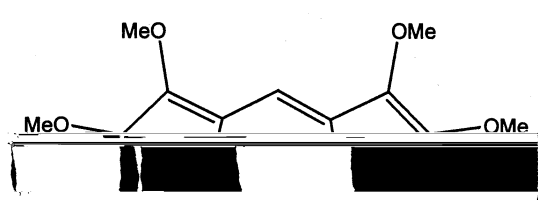


dures and distilled before use. Chemicals were obtained from Fluka and were purified before use. Reactions have been carried out under a blanket of nitrogen. Sufficient precautions have been taken to avoid exposure to bright light. $\mathrm{Zn} 1$ and $\mathrm{Ni1}$ were synthesized using their respective metal acetates following standard procedures. ${ }^{5}$ Purity of the synthesized porphyrins was checked by TLC and ${ }^{1} \mathrm{H}$ NMR spectroscopy.

\subsection{Synthesis of mesofunctionalized porphyrins}

2.1a 5-Nitro-2,3,7,8,12,13,17,18-octamethoxyporphyrin 2: $\mathrm{Zn} 1$ (100 $\mathrm{mg}, 0.16 \mathrm{mmol})$ was dissolved in a mixture of dry solvents containing dichloromethane $(200 \mathrm{ml})$ and acetonitrile $(80 \mathrm{ml})$. A solution of iodine $(45 \mathrm{mg}, 0.18 \mathrm{mmol})$ in dry dichloromethane $(40 \mathrm{ml})$ was added to it while stirring, followed by a solution of silver nitrite $(25 \mathrm{mg}, 0.162 \mathrm{mmol})$ in dry acetonitrile $(15 \mathrm{ml})$. The reaction mixture was stirred for two minutes during which period the solution color changed from dark pink to light violet. The stirring was then stopped and the reaction mixture was immediately filtered to remove the unreacted $\mathrm{AgNO}_{2}$ to avoid polynitration. The filtrate was evaporated to dryness. Dissolved in a minimum amount of chloroform and to this concentrated hydrochloric acid was added dropwise while stirring over an ice-bath. After $5 \mathrm{~min}$ the green solution was poured into icewater mixture and extracted with more of chloroform. The organic layer was dried over anhydrous $\mathrm{Na}_{2} \mathrm{SO}_{4}$ and stripped of the solvent. The residue was dissolved in a minimum amount of chloroform and chromatographed over a neutral alumina column using chloroform as the eluant. The first reddish brown band collected was the required mesonitrooctamethoxyporphyrin 2. The yield based on Zn1 was $74 \mathrm{mg}(76 \%) .{ }^{1} \mathrm{H}$ NMR $\left(400 \mathrm{MHz}, \mathrm{CDCl}_{3}\right)$ $(\mathrm{ppm}) \delta=10 \cdot 17\left(s, 2 \mathrm{H}, \mathrm{CH}_{\text {meso-adj }}\right), 10.06(s, 1 \mathrm{H}$, $\left.\mathrm{CH}_{\text {meso-opp }}\right), 4.80(s, 6 \mathrm{H}, \mathrm{OMe}), 4.79(s, 6 \mathrm{H}, \mathrm{OMe}), 4.78$ $(s, 6 \mathrm{H}, \mathrm{OMe}), 4.58(s, 6 \mathrm{H}, \mathrm{OMe}),-4.53(b s, 2 \mathrm{H}$, $\mathrm{NH})$. MALDI mass $\left(\mathrm{MH}^{+} \cdot\right)$ : $596 \cdot 9$, calcd. for $\mathrm{MH}^{+} \cdot$ $\left(\mathrm{C}_{28} \mathrm{H}_{30} \mathrm{~N}_{5} \mathrm{O}_{10}-596 \cdot 6\right)$.

\section{1b 5-Amino-2,3,7,8,12,13,17,18-octamethoxypor-} phyrin 3: Metallic tin powder $(2.5 \mathrm{~g}, 21.06 \mathrm{mmol})$ was added to $\mathrm{Zn} 2$ (200 $\mathrm{mg}, 0.30 \mathrm{mmol})$ in chloroform $(20 \mathrm{ml})$. This was followed by the addition of conc. hydrochloric acid $(15 \mathrm{ml})$ and the reaction mixture was sonicated for $30 \mathrm{~min}$. The reaction mixture was filtered and washed with water. The organic layer was extracted with chloroform and dried over anhydrous $\mathrm{Na}_{2} \mathrm{SO}_{4}$ and the solvent was removed. The product was dissolved in a minimum amount of chloroform and chromatographed over neutral alumina using chloroform:acetone $(95: 5 \mathrm{v} / \mathrm{v})$ as eluant. The column was protected from light. The yield of $\mathbf{3}$ was almost quantitative on the basis of starting material, $152 \mathrm{mg}$ (88\%). ${ }^{1} \mathrm{H}$ NMR $\left(400 \mathrm{MHz}, \mathrm{CDCl}_{3}\right)$ $(\mathrm{ppm}) \delta=9.30\left(s, 2 \mathrm{H}, \mathrm{CH}_{\text {meso-adj }}\right), 8.92(s, 1 \mathrm{H}$, $\mathrm{CH}_{\text {meso-opp }}$ ), 8.18 (bs, 2H, $\left.-\mathrm{NH}_{2}\right), 4.66(s, 6 \mathrm{H}, \mathrm{OMe})$, $4.65(s, 6 \mathrm{H}, \mathrm{OMe}), 4$ 
for $30 \mathrm{~min}$, the temperature being maintained around $50-55^{\circ} \mathrm{C}$. The reaction mixture was heated and kept at reflux for $2 \mathrm{~h}$, during which period the colour of the solution turned from red to green. The reaction mixture was cooled to room temperature and a saturated solution of sodium acetate $(150 \mathrm{ml})$ was added gradually and then heated as before for another $30 \mathrm{~min}$. At the end of this period, the reaction mixture was cooled and washed with water and the compound extracted in chloroform. The chloroform layer was separated and dried over anhydrous sodium sulphate. The compound was chromatographed on a neutral alumina column with chloroform as the eluant. The first pink band contained $\mathrm{Ni}$ (II)-derivative of the meso-formyloctamethoxyporphyrin. The yield was almost quantitative (186 mg, 89\%). ${ }^{1} \mathrm{H}$ NMR in $\mathrm{CDCl}_{3}$ ( $\delta$ in ppm): $12.34(s, 1 \mathrm{H}, \mathrm{CHO}), 9.85(s, 2 \mathrm{H}$, meso-H), $9.82(s, 1 \mathrm{H}$, meso-H), $4.69(s, 12 \mathrm{H}$, $\left.\mathrm{OCH}_{3}\right), 4.59\left(s, 6 \mathrm{H}, \mathrm{OCH}_{3}\right), 4.44\left(s, 6 \mathrm{H}, \mathrm{OCH}_{3}\right)$.

Free-base formylporphyrin was obtained by acid demetallation reaction of the above $\mathrm{Ni}$ (II)-derivative $(186 \mathrm{mg})$ with concentrated $\mathrm{H}_{2} \mathrm{SO}_{4}(20 \mathrm{ml})$. The compound was chromatographed on a neutral alumina column with chloroform as the eluant. The first reddish brown fraction collected was the required porphyrin 5. The yield was almost quantitative $(150 \mathrm{mg}$, $88 \%) .{ }^{1} \mathrm{H}$ NMR $\left(400 \mathrm{MHz}, \mathrm{CDCl}_{3}\right)(\mathrm{ppm}) \delta=12.49$ $(s, 1 \mathrm{H},-\mathrm{CHO}), 10 \cdot 11\left(s, 2 \mathrm{H}, \mathrm{CH}_{\text {meso-adj }}\right), 10.03(s$, $\left.1 \mathrm{H}, \mathrm{CH}_{\text {meso-opp }}\right), 4.79(s, 12 \mathrm{H}, \mathrm{OMe}), 4.75(s, 6 \mathrm{H}$, $\mathrm{OMe}), 4.55$ ( $s, 6 \mathrm{H}, \mathrm{OMe}),-4.33$ (bs, 2H, NH). MALDI mass $\left(\mathrm{MH}^{+}\right)^{\circ}: 579.9$, calcd. for $\mathrm{MH}^{+}$. $\left(\mathrm{C}_{29} \mathrm{H}_{31} \mathrm{~N}_{4} \mathrm{O}_{9}-579 \cdot 6\right)$.

2.1e 5-Hydroxymethyl-2,3,7,8,12,13,17,18-octamethoxyporphyrin 6: A solution of sodium borohydride $(25 \mathrm{mg}, 0.66 \mathrm{mmol})$ in dry methanol $(30 \mathrm{ml})$ was added to 5-formyloctamethoxyporphyrin, $5(50 \mathrm{mg}$, $0.086 \mathrm{mmol})$ in dry chloroform $(25 \mathrm{ml})$ while stirring, and stirring was continued overnight at room temperature. At the end of this period, the reaction mixture was washed with water and the organic layer extracted with chloroform and dried over anhydrous sodium sulphate, and the solvent finally removed. The residue was dissolved in a minimum amount of chloroform and chromatographed over a neutral alumina column with chloroform as eluant. The first fraction eluted with chloroform gave unreacted formyl derivative and the second fraction eluted with $\mathrm{CHCl}_{3}$ : acetone $(90: 10 \mathrm{v} / \mathrm{v})$ was the desired hydroxymethyl porphyrin 6 (42 mg, 84\%). ${ }^{1} \mathrm{H}$ NMR $\left(400 \mathrm{MHz}, \mathrm{CDCl}_{3}\right)(\mathrm{ppm}) \delta=10 \cdot 11\left(s, 2 \mathrm{H}, \mathrm{CH}_{\text {meso-adj }}\right)$, $9.93\left(s, 1 \mathrm{H}, \mathrm{CH}_{\text {meso-opp }}\right), 6.98\left(s, 1 \mathrm{H},-\mathrm{CH}_{2}-\right), 6.94(s$, $\left.1 \mathrm{H},-\mathrm{CH}_{2}-\right), 4.80(s, 6 \mathrm{H}, \mathrm{OMe}), 4.79(s, 6 \mathrm{H}, \mathrm{OMe})$, $4.78(s, 6 \mathrm{H}, \mathrm{OMe}), 4.74(s, 6 \mathrm{H}, \mathrm{OMe}),-4.07(b s$, $1 \mathrm{H}, \mathrm{NH}),-3.95(b s, 1 \mathrm{H}, \mathrm{NH})$. MALDI mass $\left(\mathrm{MH}^{+}\right)$: 582.0, calcd. for $\mathrm{MH}^{+} \cdot\left(\mathrm{C}_{29} \mathrm{H}_{33} \mathrm{~N}_{4} \mathrm{O}_{9}-581 \cdot 6\right)$.

\section{1f $2,3,7,8,12,13,17,18$-Octamethoxyporphyrin-5-} carbaldehyde oxime 7: Hydroxylamine.hydrochloride (30 mg, $0.43 \mathrm{mmol}$ ) was added to 5-formyloctamethoxyporphyrin $5(50 \mathrm{mg}, 0.086 \mathrm{mmol})$ in pyridine $(70 \mathrm{ml})$. The reaction mixture was heated on a water-bath for $30 \mathrm{~min}$ and immediately poured into water $(100 \mathrm{ml})$ and extracted with chloroform. Subsequent to the removal of the solvent, the product was chromatographed over a neutral alumina column. The first band eluted with chloroform was found to be unreacted material. The second band eluted with $\mathrm{CHCl}_{3}$ : acetone $(90: 10 \mathrm{v} / \mathrm{v})$ was the desired oxime derivative 7, yield: $45 \mathrm{mg}(88 \%) .{ }^{1} \mathrm{H}$ NMR (400 MHz, $\left.\mathrm{CDCl}_{3}\right)(\mathrm{ppm}) \delta=10 \cdot 40(s, 1 \mathrm{H}, \mathrm{CH}=\mathrm{N}), 10 \cdot 12(\mathrm{~s}, 2 \mathrm{H}$, $\left.\mathrm{CH}_{\text {meso-adj }}\right), 10 \cdot 00\left(s, 1 \mathrm{H}, \mathrm{CH}_{\text {meso-opp }}\right), 7.53(\mathrm{bs}, 1 \mathrm{H}$, $-\mathrm{NOH}), 4.79(s, 12 \mathrm{H}, \mathrm{OMe}), 4.77(s, 6 \mathrm{H}, \mathrm{OMe}), 4.54$ $(s, 6 \mathrm{H}, \mathrm{OMe}),-4 \cdot 21(b s, 2 \mathrm{H}, \mathrm{NH})$. MALDI mass $\left(\mathrm{MH}^{+\bullet}\right)$ : 594.2, calcd. for $\mathrm{MH}^{+\cdot}\left(\mathrm{C}_{29} \mathrm{H}_{32} \mathrm{~N}_{5} \mathrm{O}_{9}-594 \cdot 6\right)$.

\section{1g 5-Cyano-2,3,7,8,12,13,17,18-octamethoxypor-}

phyrin 8: The oxime derivative $7(50 \mathrm{mg}, 0.08 \mathrm{mmol}$ ) in acetic anhydride $(50 \mathrm{ml})$ was refluxed for $1 \mathrm{~h}$ by protecting the reaction mixture from moisture with a $\mathrm{CaCl}_{2}$ guard tube. At the end of the reaction, the reaction mixture was poured in to water $(100 \mathrm{ml})$ and vigorously stirred for $1 \mathrm{~h}$, extracted with chloroform and dried over anhydrous $\mathrm{Na}_{2} \mathrm{SO}_{4}$. Then the solvent was removed, the product dissolved in a minimum amount of chloroform and chromatographed over neutral alumina column using chloroform as eluant. The bluish-purple first fraction was the desired cyano derivative 8, yield: $41 \mathrm{mg}(84 \%)$. ${ }^{1} \mathrm{H}$ NMR $\left(400 \mathrm{MHz}, \mathrm{CDCl}_{3}\right)(\mathrm{ppm}) \delta=10.06\left(s, 2 \mathrm{H}, \mathrm{CH}_{\text {meso-adj }}\right)$, $9.94\left(s, 1 \mathrm{H}, \mathrm{CH}_{\text {meso-opp }}\right), 4.88(s, 6 \mathrm{H}, \mathrm{OMe}), 4.78(s$, $6 \mathrm{H}, \mathrm{OMe}), 4.77(s, 6 \mathrm{H}, \mathrm{OMe}), 4.71$ (s, 6H, OMe), $-4 \cdot 17(b s, 2 \mathrm{H}, \mathrm{NH})$. MALDI mass $\left(\mathrm{MH}^{+}{ }^{\circ}\right): 577 \cdot 0$, calcd. for $\mathrm{MH}^{+} \cdot\left(\mathrm{C}_{29} \mathrm{H}_{30} \mathrm{~N}_{5} \mathrm{O}_{8}-576 \cdot 6\right)$.

\section{1h 5-Carboxy-2,3,7,8,12,13,17,18-octamethoxy-} porphyrin 9: Meso-cyanooctamethoxyporphyrin 8 (50 $\mathrm{mg}, 0.087 \mathrm{mmol}$ ) was dissolved in concentrated sulphuric acid $(4 \mathrm{ml})$ and glacial acetic acid $(4 \mathrm{ml})$ and heated on a steam bath for $1 \mathrm{~h}$. The reaction mixture was poured into an ice-bath and extracted with chloroform. The organic layer was washed with 
saturated sodium bicarbonate solution and dried over anhydrous $\mathrm{Na}_{2} \mathrm{SO}_{4}$. The solvent was removed and the product was chromatographed over a neutral alumina column with chloroform as eluant. The first two light fractions contained the octamethoxyporphyrin 1 (obtained owing to decarboxylation) and the unreacted starting material whereas the third major fraction eluted with $\mathrm{CHCl}_{3}:$ acetone $(80: 20 \mathrm{v} / \mathrm{v})$ contained the desired carboxy derivative 9. Yield: $41 \mathrm{mg}$ (79\%). ${ }^{1} \mathrm{H}$ NMR (400 MHz, $\left.\mathrm{CDCl}_{3}\right)$ (ppm) $\delta=10.07\left(s, 2 \mathrm{H}, \mathrm{CH}_{\text {meso-adj }}\right), 9.88\left(s, 1 \mathrm{H}, \mathrm{CH}_{\text {meso-opp }}\right)$, $4.79(s, 6 \mathrm{H}, \mathrm{OMe}), 4.77(s, 12 \mathrm{H}, \mathrm{OMe}), 4.62(s, 6 \mathrm{H}$, $\mathrm{OMe}),-4.45(b s, 2 \mathrm{H}, \mathrm{NH})$. MALDI mass $\left(\mathrm{M}^{+}{ }^{\circ}\right)$ : 594.9, calcd. for $\mathrm{M}^{+} \cdot\left(\mathrm{C}_{29} \mathrm{H}_{30} \mathrm{~N}_{4} \mathrm{O}_{10}-594.6\right)$.

\subsection{Methods}

PMR spectra of the porphyrins were recorded on a Bruker AMX $400 \mathrm{MHz}$ FTNMR spectrometer using TMS as internal standard (chemical shifts in $\delta$, ppm). Optical absorption spectra were obtained on a Hitachi U-3000 UV-Vis spectrophotometer using a pair of matched quartz cells of $10 \mathrm{~mm}$ path length at an ambient temperature of $300 \mathrm{~K}$. MALDI-mass spectra of the porphyrins were recorded on a Kratos PC-Kompact MALDI Data System at room temperature using alpha-cyano-4-hydroxy cinnamic acid or sinnapinic acid matrix. The protonation equilibria of the meso-substituted porphyrins were examined using optical absorption method. The spectra of the porphyrins were recorded on increasing addition of trifluoroacetic acid in a $\mathrm{CHCl}_{3}: \mathrm{CH}_{3} \mathrm{OH}(1: 1)$ solvent mixture at room temperature. The decrease in the absorption of the band around $530 \mathrm{~nm}$ was monitored as a function of the increasing concentration of the acid. For 3, 4 and 8, the bands at 514, 543 and $635 \mathrm{~nm}$ were monitored respectively. The $\mathrm{pH}$ of the reaction medium was measured using an Elico model L1-120 digital pH meter using a glass electrode. The response of the electrode was calibrated using a standard buffer solution of known $\mathrm{pH}$. The $\mathrm{p} K_{4}$ value was obtained from Henderson's plot of $\log \left[\left(A_{0}-A\right) /\left(A-A_{\infty}\right)\right]$ versus $\mathrm{pH}$, where $A_{0}, A_{\infty}$ and $A$ are the absorbance of the free-base porphyrin, completely protonated species and the mixture of freebase and protonated forms respectively.

AM1 calculations to obtain changes in the spectra and other properties of the porphyrins upon mesosubstitution were performed using MOPAC. ${ }^{6}$ This method of calculation is known for the validity of prediction both in relation to experimental data and with respect to elaborate theoretical methods. These semi-empirical calculations include full configuration interaction $(\mathrm{CI}=8)$ within the orbitals of four orbital method (FOM). The optimized structures of all the porphyrins were obtained using AM1 and semiempirical calculations were performed upon them.

\section{$2.3 X$-ray crystallographic studies}

Among the many attempts made to obtain single crystals of the meso-substituted free-base octamethoxyporphyrins, we have been successful in obtaining only the cyano derivative of the free-base octamethoxyporphyrin in the form of single crystals by slow evaporation of chloroform and toluene $(1: 1 \mathrm{v} / \mathrm{v})$ solution of $\mathbf{8}$ at room temperature. A suitable single crystal was carefully selected under a polarizing microscope and glued to a thin glass fibre with cyanoacrylate (super glue) adhesive. Single crystal structure determination by X-ray diffraction was performed on a Siemens Smart-CCD diffractometer equipped with a normal focus, $2.4 \mathrm{~kW}$ sealed tube X-ray source $\left(\right.$ Mo- $\mathrm{K}_{\alpha}$ radiation, $\lambda=0.71073 \AA$ ) operating at $50 \mathrm{kV}$ and $40 \mathrm{~mA}$. A hemisphere of intensity data was collected at room temperature in 1321 frames with $\omega$ scans (width of $0.30^{\circ}$ and exposure time of 20 s per frame) in the $2 \theta$ range 3 to $46 \cdot 5^{\circ}$. Relevant crystal data are presented in table 1 .

The structure was solved by direct methods using SHELXS-86 and difference Fourier syntheses. All the hydrogen positions were initially located in the difference Fourier maps, but for the final refinement the hydrogen atoms were placed geometrically. No absorption correction was applied. The last cycles of refinement included atomic positions for all the atoms, anisotropic thermal parameters for all non-hydrogen atoms and isotropic thermal parameters for all the hydrogen atoms. Full-matrix-least-squares structure refinement against $\left|F^{2}\right|$ was carried out using the SHELXL-97 package of programs. ${ }^{7}$ Details of CIF files are available from the Cambridge Crystallographic Data Centre, 12 Union Road, Cambridge CB2 1EZ, UK on request quoting the deposition number CCDC 260877.

\section{Results and discussion}

Interestingly, 1 does not undergo nitration like other $\beta$-substituted octaalkylporphyrins with common nitrating agents like concentrated nitric acid either in acetic or sulphuric acids, prolonged reaction time or 
Table 1. Crystallographic data and structure refinement parameters for $\mathbf{8}$.

\begin{tabular}{|c|c|c|}
\hline Identification code & \multicolumn{2}{|l|}{ CNOMP } \\
\hline Empirical formula & \multicolumn{2}{|l|}{$\mathrm{C}_{29} \mathrm{H}_{29} \mathrm{~N}_{5} \mathrm{O}_{8}$} \\
\hline Formula weight & \multicolumn{2}{|l|}{$575 \cdot 57$} \\
\hline Temperature & \multicolumn{2}{|l|}{$293(2) \mathrm{K}$} \\
\hline Wavelength & \multicolumn{2}{|l|}{$0.71073 \AA$} \\
\hline Crystal system & \multicolumn{2}{|l|}{ Monoclinic } \\
\hline Space group & \multicolumn{2}{|l|}{$P 2_{1} / c$} \\
\hline \multirow[t]{2}{*}{ Unit cell dimensions } & $\begin{array}{l}a=9 \cdot 0759(6) \AA \\
b=13 \cdot 3631(7) \AA \\
c=23 \cdot 3001(15) \AA\end{array}$ & $\begin{array}{l}\alpha=90^{\circ} \\
\beta=100 \cdot 871(2)^{\circ} \\
\gamma=90^{\circ}\end{array}$ \\
\hline & \multicolumn{2}{|l|}{$2775 \cdot 2(3) \AA^{3}$} \\
\hline$Z$ & \multicolumn{2}{|l|}{4} \\
\hline Density (calculated) & \multicolumn{2}{|l|}{$1 \cdot 378 \mathrm{Mg} / \mathrm{m}^{3}$} \\
\hline Absorption coefficient & \multicolumn{2}{|l|}{$0 \cdot 102 \mathrm{~mm}^{-1}$} \\
\hline$F(000)$ & \multicolumn{2}{|l|}{1208} \\
\hline Crystal size & \multicolumn{2}{|c|}{$0.04 \times 0.08 \times 0.20 \mathrm{~mm}^{3}$} \\
\hline Theta range for data collection & \multicolumn{2}{|c|}{1.76 to $23 \cdot 31^{\circ}$} \\
\hline Index ranges & \multicolumn{2}{|c|}{$-9 \leq h \leq 10,-14 \leq k \leq 13,-20 \leq 1 \leq 25$} \\
\hline Reflections collected & \multicolumn{2}{|c|}{11148} \\
\hline Independent reflections & \multicolumn{2}{|c|}{$3970[R$ (int $)=0.0798]$} \\
\hline Completeness to theta $=23.31^{\circ}$ & \multicolumn{2}{|c|}{$99.3 \%$} \\
\hline Refinement method & \multicolumn{2}{|c|}{ Full-matrix least-squares on $F^{2}$} \\
\hline Data/restraints/parameters & \multicolumn{2}{|c|}{$3970 / 0 / 380$} \\
\hline Goodness-of-fit on $F^{2}$ & \multicolumn{2}{|l|}{1.065} \\
\hline Final $R$ indices $[I>2 \sigma(I)]$ & \multicolumn{2}{|c|}{$R 1=0.0719, w R 2=0.1725$} \\
\hline$R$ indices (all data) & \multicolumn{2}{|c|}{$R 1=0 \cdot 1613, w R 2=0 \cdot 2163$} \\
\hline Extinction coefficient & \multicolumn{2}{|c|}{$0.0013(6)$} \\
\hline Largest diff. peak and hole & \multicolumn{2}{|c|}{0.410 and -0.232 e. $\AA^{-3}$} \\
\hline
\end{tabular}

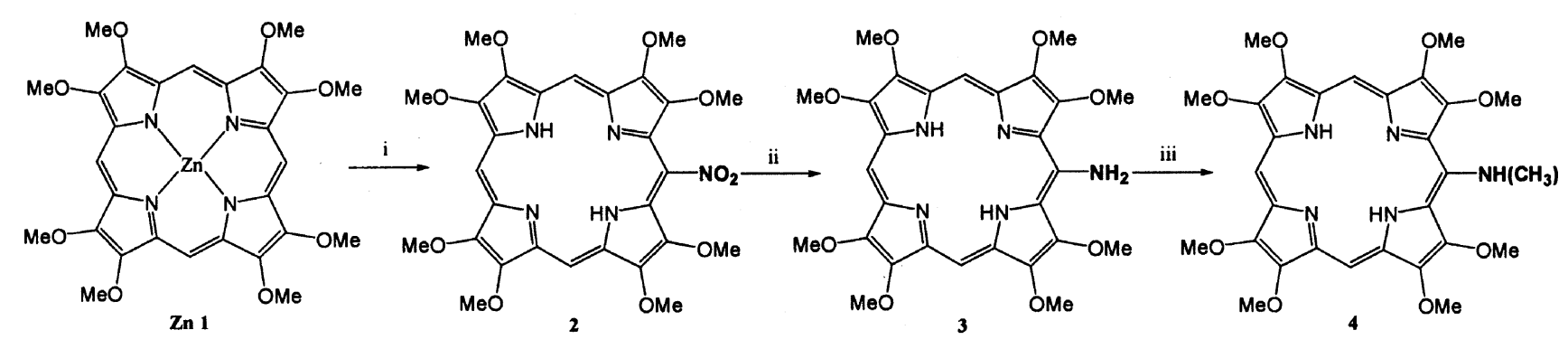

Conditions: (i) $\mathrm{I}_{2} / \mathrm{AgNO}_{2}, \mathrm{CH}_{2} \mathrm{Cl}_{2} / \mathrm{CH}_{3} \mathrm{CN}$, stir, 2 min, conc. $\mathrm{H}_{2} \mathrm{SO}_{4}$; (ii) $\mathrm{Sn} / \mathrm{HCl}$, sonicate, $30 \mathrm{~min}$; (iii) Copper acetate, $\mathrm{NaBH}$, THF, $3 \mathrm{M} \mathrm{H}_{2} \mathrm{SO}_{4}, 40 \%$ aq. $\mathrm{HCHO}$, conc. $\mathrm{H}_{2} \mathrm{SO}_{4}$. Yields: $2-76 \% ; 3-88 \% ; 4-26 \%$

\section{Scheme 1.}

elevated temperature resulting in degradation of the starting material, whereas nitration with copper nitrate in acetic anhydride results in the copper derivative of the nitro-substituted porphyrin $\mathbf{2}$ in very low yield. However, $\mathrm{Zn} \mathbf{1}$ can be readily nitrated with iodine and $\mathrm{AgNO}_{2}$ in $\mathrm{CH}_{2} \mathrm{Cl}_{2} / \mathrm{CH}_{3} \mathrm{CN}$ (scheme 1). ${ }^{8}$ The reaction proceeds vigorously and has to be quenched in about $2 \mathrm{~min}$ to avoid polynitration. The $\mathrm{Sn} / \mathrm{HCl}$ reduction ${ }^{9}$ of $\mathrm{Cu} 2$ followed by acid demetallation with concentrated sulphuric acid produces the mesoamino derivative 3 in high yield. However, Zn2 undergoes the above reduction process to form $\mathbf{3}$ directly in quantitative yield. Attempts to N-permethylate $\mathbf{3}$ remain unsuccessful so far. To avoid methylation of the core imino nitrogens, we used the copper derivative of 3. With formaldehyde/sodium borohydride in 


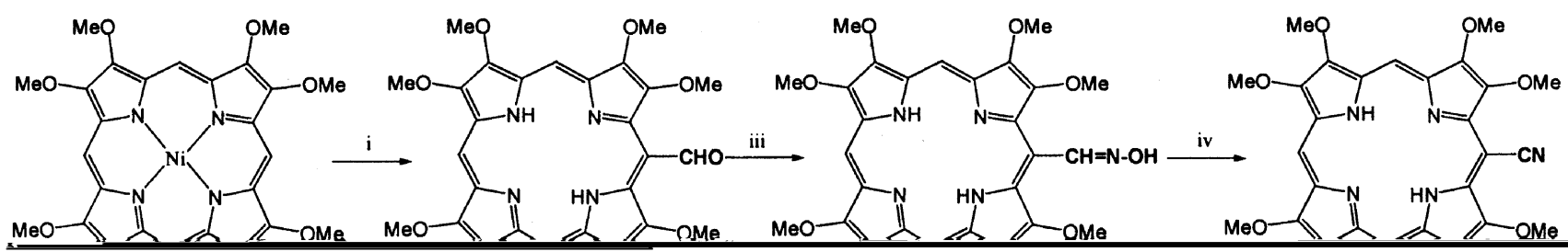

Conditions: (i) $\mathrm{POCl}_{3}$ to $\mathrm{DMF}$ at $0^{\circ}$, dichloroethane, reflux $2 \mathrm{~h}$, sat. $\mathrm{NaOAc}$, reflux 30 min, conc. $\mathrm{H}_{2} \mathrm{SO}_{4} ;\left(\right.$ ii) $\mathrm{NaBH}_{4}, \mathrm{CHCl}_{3} / \mathrm{MeOH}$, stir, r.t., $12 \mathrm{~h}$; (iii) $\mathrm{NH}_{2} \mathrm{OH} . \mathrm{HCl}$, Pyridine, steam bath, $30 \mathrm{~min}$; (iv) $\mathrm{Ac}_{2} \mathrm{O}$, reflux, $1 \mathrm{~h}$; (v) Glacial AcOH/conc. $\mathrm{H}_{2} \mathrm{SO}_{4}(1: 1 \mathrm{v} / \mathrm{v})$ steam bath, 1 h. Yields: $5-89 \% ; 6-84 \% ; 7-88 \% ; 8-84 \% ; 9-79 \%$

\section{Scheme 2.}

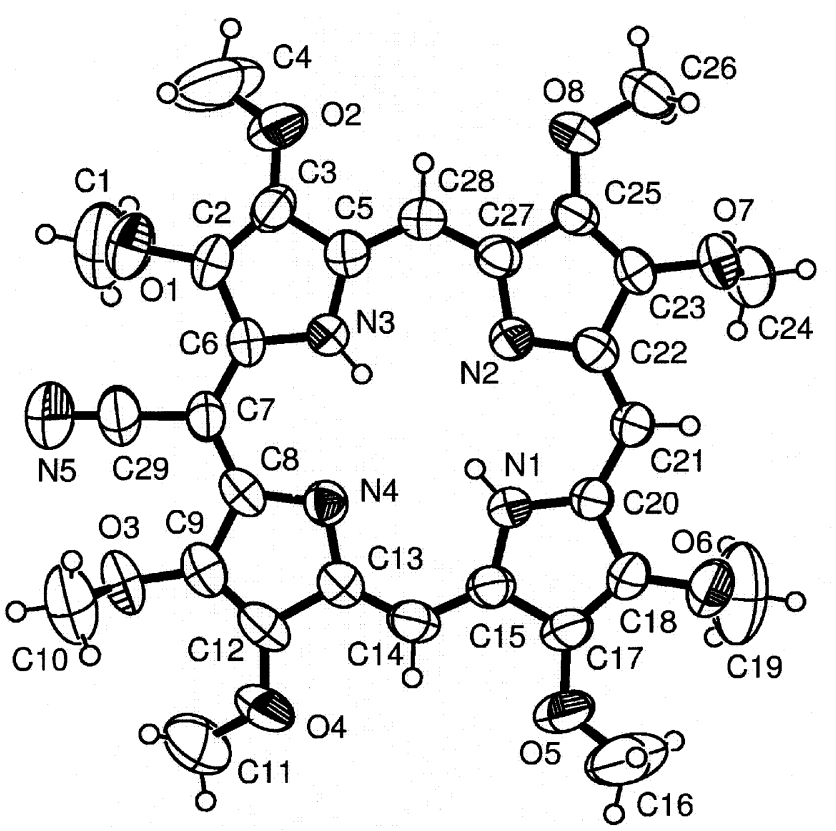

Figure 1. ORTEP diagram of free-base meso-substituted cyanooctamethoxyporphyrin $\mathbf{8}$ showing $50 \%$ thermal ellipsoid probability.

aqueous sulphuric acid ${ }^{10}$ only mono-methylated derivative 4 could be obtained in lesser yield among with other unidentified products. 


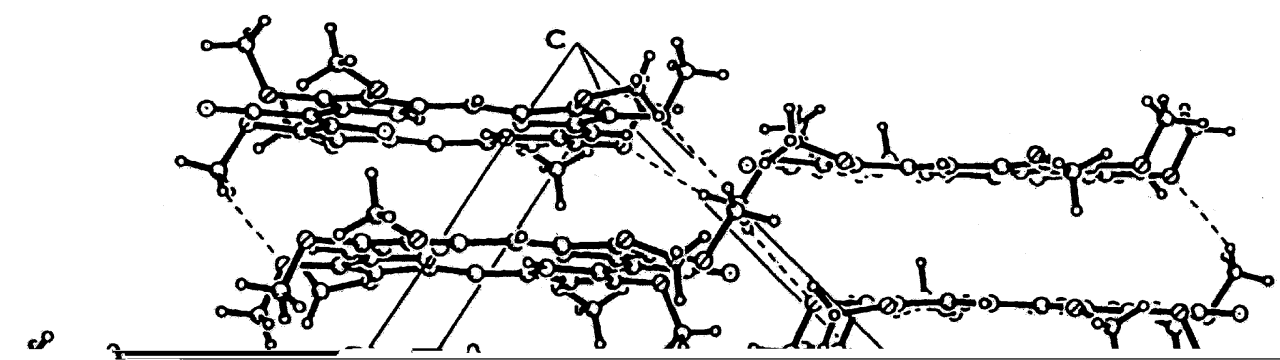

Figure 2. Crystallographic packing diagram of free-base meso-substituted cyanooctamethoxyporphyrin $\mathbf{8}$.

Table 2. Selected bond lengths $(\AA)$ and bond angles $\left(^{\circ}\right)$ of meso-cyanosubstituted octamethoxyporphyrin ${ }^{\mathrm{a}}$.

\begin{tabular}{lccc}
\hline Bond & Distance $(\AA)$ & Atoms & Angle $\left(^{\circ}\right)$ \\
\hline $\mathrm{C}(1)-\mathrm{O}(1)$ & $1.375(8)$ & $\mathrm{C}(3)-\mathrm{C}(2)-\mathrm{O}(1)$ & $127 \cdot 6(5)$ \\
$\mathrm{C}(2)-\mathrm{C}(3)$ & $1.348(6)$ & $\mathrm{C}(3)-\mathrm{C}(2)-\mathrm{C}(6)$ &
\end{tabular}


leading to the conclusion that the presence of cyano group does not cause any steric distortion to the porphyrin ring. ${ }^{4 a}$ The methoxy groups are arranged in a fashion that the planar methoxy groups point away from the meso-hydrogen atoms, forcing the neighboring methoxy group on the same pyrrole ring out of the plane. The structure of this porphyrin provides a basis for the interpretation of the observed spectral data.

All the porphyrin derivatives were characterized by ${ }^{1} \mathrm{HNMR}$, UV-Vis and MALDI-mass spectroscopy techniques. The ${ }^{1} \mathrm{HNMR}$ data of freebase porphyrins display the characteristic resonances of methine, imino and methoxy protons. Interestingly, the presence of a substituent on one of the meso-carbons results in the splitting of the methine protons resonances and the signals arising from the methoxy protons located at the pyrrole rings become clearly distinguishable. Based on the integrated intensity data, it is found that the methine proton located opposite to the meso-substituent apparently resonates in a shielded region while the two methine protons situated at the neighbouring methine carbons occur at a marginally deshielded region relative to the corresponding resonance of $\mathbf{1}$. This shielding and deshielding of methine proton resonances as a consequence of meso-substitution is observed for all the mesosubstituted porphyrins. However, in the case of amino and N-methylamino derivatives, both the opposite and adjacent methine proton signals occur in a shielded region relative to that observed for $\mathbf{1}$. The methoxy protons, in general, split into four sets of signals, one being more shielded than the others. In case of the cyano-derivative the resonance of one of the methoxy groups occurs in a more deshielded region than the resonances of other methoxy groups. The imino protons, in general, resonate at a lower field compared to the unsubstituted octamethoxyporphyrin. The deshielding effect experienced by these resonances is found to be more, particularly in case of the amino- and N-methylamino-derivatives. The nitro and carboxy derivatives show a marginal shielding effect. Interestingly, in case of the amino and hydroxymethyl derivatives, an inequivalence of imino protons is observed as revealed by the appearance of two singlets.

The above observations could be interpreted as follows: meso-substitution leads to a depletion of ring current in the porphyrin core. The shielding of the methine protons resonance (located opposite to the meso-substituents) can be ascribed to a conforma- tional change in which the entire molecule is folded across the two opposite meso positions. ${ }^{13}$ This results in diminishing the deshielding effects at the substituted meso-position and at the one opposite to it. Protons in the vicinity of the meso-substituents experience an additional shielding effect. This can be understood in terms of the steric influence caused by the nonlinear substituents, which are forced out of the plane of the macrocycle; but magnetic anisotropy associated with the meso-substituents seems to play a predominant role. ${ }^{14}$ In case of the formyl, carboxy, oxime and the nitro derivatives, the neighbouring $\beta$ methoxy substituents are in a region of positive shielding (most shielded resonance) because of the preferred out-of-plane conformation of the mesosubstituents. However, the linearity of the cyanogroup helps it to align with the plane of the marocycle and hence the proton resonances arising from neighbouring methoxy groups experience a strong deshielding effect due to the magnetic anisotropy of the cyano-group. The introduction of a meso-amino substituent causes strong shielding of methine and methoxy proton resonances while a deshielding effect is experienced by the imino proton resonances. This apparently arises from the strong electron-donating nature of the amine group $\left(\sigma_{p}:-0 \cdot 66\right)$; the amino protons resonating at $8.18 \mathrm{ppm}\left(\mathrm{NH}_{2}\right.$ of $\mathrm{OEPNH}_{2}$ resonates at $6.14 \mathrm{ppm}^{3 \mathrm{c}}$ ) support the strong involvement in conjugation with the ring. N-methylation of the amino group shifts the resonance of the $\mathrm{NH}$ proton upfield $(8.00 \mathrm{ppm})$. The formyl proton resonates at $12: 49 \mathrm{ppm}$ and shifts upfield on oxime formation $(10.40 \mathrm{ppm})$. It is of interest to note that the methylene protons of 6 resonate as two close-lying singlets (6.94 and $6.98 \mathrm{ppm}$ ). This may be attributed to possible hydrogen bonding between substituent and the neighbouring methoxy group (loc. cit) making the methylene protons diasteriomeric in nature.

The UV-Vis spectra of some of the substituted porphyrin are presented in figure 3 . The absorption spectral data are presented in table 3 . All the porphyrins display characteristic Soret band ( $B$ band) and four $Q$ bands in the visible region. These transitions are interpreted in terms of the four-orbital model of Gouterman. ${ }^{15}$ It is seen that all the observed bands of the meso-substituted porphyrins are redshifted relative to the unsubstituted porphyrin 1 . The meso substitution of $\mathbf{1}$ leads to change in the spectral pattern of the $Q$ band region of these porphyrins.

The porphyrins $2,5,6,7$, and 9 show a change from rhodo- to etio-type spectra; 3 has $Q 4>Q 1>$ 
Table 3. Optical absorption data of the free-base meso-substituted octamethoxyporphyrins in dichloromethane at $298 \mathrm{~K}$.

\begin{tabular}{|c|c|c|c|c|c|c|c|}
\hline \multirow[b]{2}{*}{ Porphyrins } & \multicolumn{5}{|c|}{$\lambda_{\max }(\mathrm{nm}), \log \varepsilon$} & \multirow{2}{*}{$\begin{array}{c}F w h m \\
B_{x}(0,0)\left(\mathrm{cm}^{-1}\right)\end{array}$} & \multirow{2}{*}{$\begin{array}{c}F w h m \\
Q_{x}(0,0)\left(\mathrm{cm}^{-1}\right)\end{array}$} \\
\hline & $B_{x}(0,0)$ & $Q_{y}(1,0)$ & $Q_{y}(0,0)$ & $Q_{x}(1,0)$ & $Q_{x}(0,0)$ & & \\
\hline 1 & $\begin{array}{l}378 \cdot 0 \\
(5 \cdot 21)\end{array}$ & $\begin{array}{l}496 \cdot 0 \\
(4 \cdot 02)\end{array}$ & $\begin{array}{l}533 \cdot 0 \\
(4 \cdot 10)\end{array}$ & $\begin{array}{l}564 \cdot 0 \\
(3 \cdot 84)\end{array}$ & $\begin{array}{l}618 \cdot 0 \\
(3 \cdot 83)\end{array}$ & 2329 & 328 \\
\hline 2 & $\begin{array}{l}380 \cdot 2 \\
(5 \cdot 22)\end{array}$ & $\begin{array}{l}499 \cdot 5 \\
(4 \cdot 02)\end{array}$ & $\begin{array}{l}536 \cdot 0 \\
(4 \cdot 00)\end{array}$ & $\begin{array}{l}568 \cdot 0 \\
(3 \cdot 82)\end{array}$ & $\begin{array}{l}622 \cdot 0 \\
(3 \cdot 77)\end{array}$ & 2301 & 380 \\
\hline 3 & $\begin{array}{l}409 \cdot 0 \\
(5 \cdot 29)\end{array}$ & $\begin{array}{l}515 \cdot 6 \\
(4 \cdot 21)\end{array}$ & $\begin{array}{l}552 \cdot 0 \\
(4 \cdot 04)\end{array}$ & $\begin{array}{l}587 \cdot 8 \\
(3 \cdot 88)\end{array}$ & $\begin{array}{l}643 \cdot 6 \\
(4 \cdot 19)\end{array}$ & 2411 & 635 \\
\hline 4 & $\begin{array}{l}415 \cdot 0 \\
(5 \cdot 30)\end{array}$ & $\begin{array}{l}518 \cdot 4 \\
(4 \cdot 19)\end{array}$ & $\begin{array}{l}556 \cdot 4 \\
(3 \cdot 89)\end{array}$ & $\begin{array}{l}588 \cdot 4 \\
(3 \cdot 77)\end{array}$ & $\begin{array}{l}647 \cdot 4 \\
(3 \cdot 89)\end{array}$ & 2370 & 722 \\
\hline 5 & $\begin{array}{l}382 \cdot 4 \\
(5 \cdot 23)\end{array}$ & $\begin{array}{l}499 \cdot 5 \\
(4 \cdot 00)\end{array}$ & $\begin{array}{l}536 \cdot 0 \\
(3 \cdot 99)\end{array}$ & $\begin{array}{l}568 \cdot 0 \\
(3 \cdot 79)\end{array}$ & $\begin{array}{l}622 \cdot 0 \\
(3 \cdot 71)\end{array}$ & 2288 & 291 \\
\hline 6 & $\begin{array}{l}384 \cdot 6 \\
(5 \cdot 20)\end{array}$ & $\begin{array}{l}501 \cdot 0 \\
(4 \cdot 07)\end{array}$ & $\begin{array}{l}537 \cdot 5 \\
(3 \cdot 99)\end{array}$ & $\begin{array}{l}569 \cdot 5 \\
(3 \cdot 84)\end{array}$ & $\begin{array}{l}624 \cdot 4 \\
(3 \cdot 65)\end{array}$ & 2438 & 358 \\
\hline 7 & $\begin{array}{l}384 \cdot 0 \\
(5 \cdot 34)\end{array}$ & $\begin{array}{l}500 \cdot 5 \\
(4 \cdot 08)\end{array}$ & $\begin{array}{l}536 \cdot 5 \\
(4 \cdot 03)\end{array}$ & $\begin{array}{l}569 \cdot 0 \\
(3 \cdot 83)\end{array}$ & $\begin{array}{l}623 \cdot 0 \\
(3 \cdot 73)\end{array}$ & 2356 & 378 \\
\hline 8 & $\begin{array}{l}388 \cdot 4 \\
(5 \cdot 26)\end{array}$ & $\begin{array}{l}509 \cdot 5 \\
(3 \cdot 98)\end{array}$ & $\begin{array}{l}548 \cdot 0 \\
(4 \cdot 07)\end{array}$ & $\begin{array}{l}579 \cdot 5 \\
(3 \cdot 80)\end{array}$ & $\begin{array}{l}635 \cdot 5 \\
(4 \cdot 00)\end{array}$ & 2026 & 435 \\
\hline 9 & $\begin{array}{l}381 \cdot 2 \\
(5 \cdot 12)\end{array}$ & $\begin{array}{l}498 \cdot 0 \\
(4 \cdot 00)\end{array}$ & $\begin{array}{l}535 \cdot 0 \\
(3 \cdot 97)\end{array}$ & $\begin{array}{l}566 \cdot 5 \\
(3 \cdot 79)\end{array}$ & $\begin{array}{l}620 \cdot 5 \\
(3 \cdot 69)\end{array}$ & 2224 & 321 \\
\hline
\end{tabular}

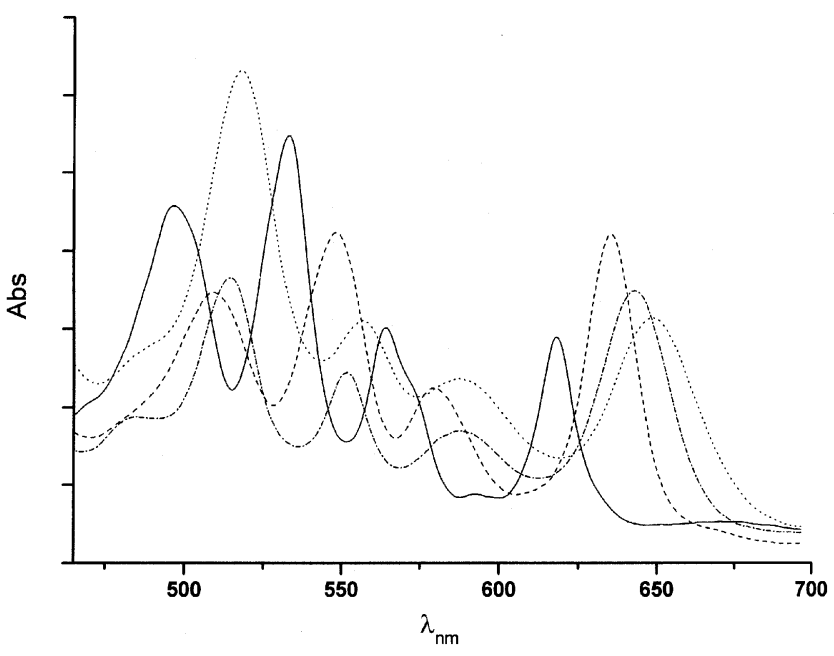

Figure 3. Electronic absorption spectra (Q-bands) of: 1 $(-), 3(-\cdots \cdot), 4(\cdots \cdots), 8(---)$ in $\mathrm{CH}_{2} \mathrm{Cl}_{2}$.

$Q 3>Q 2 ; 4$ has $Q 4>Q 3=Q 1>Q 2$ and 8 shows $Q 3>Q 1>Q 4>Q 2$ pattern. The cyano and amino derivatives show intramolecular charge transfer as evidenced from the strong enhancement of intensity of the longest wavelength $Q$ bands (figure 3). This is attributed to the presence of substituents like cyano and amino groups at the meso position that are strongly conjugated to the electron-rich octamethoxyporphyrin skeleton. Methylation of the amino group substantially reduces the intensity of the $Q$ band possibly due to steric reasons, which diminishes the efficiency of charge-transfer.

In spite of the presence of eight electron-donating methoxy groups, all the porphyrins show poor basi- 


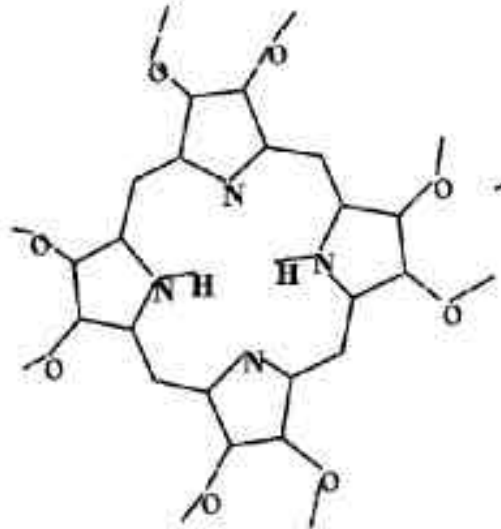

OMP

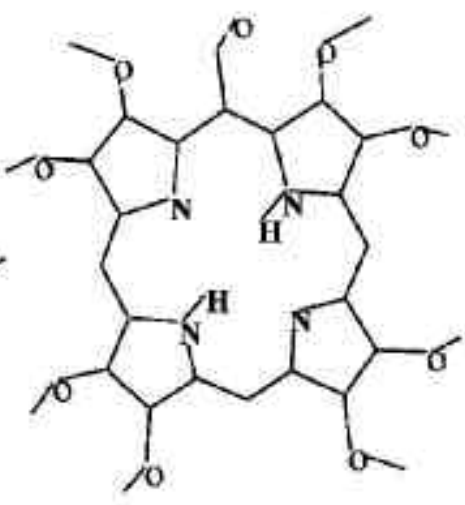

FOMP

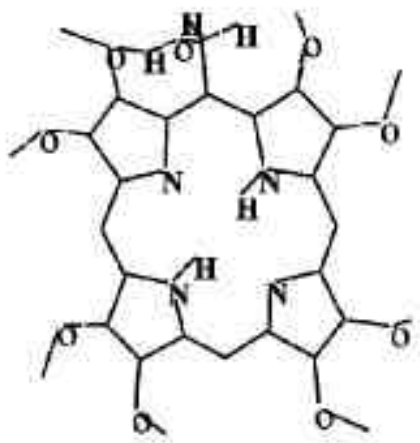

HMOMP

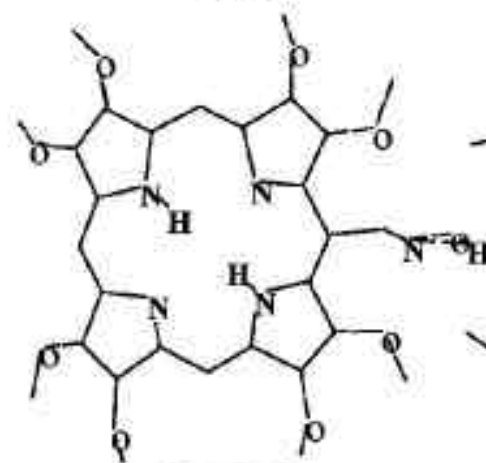

OXOMP

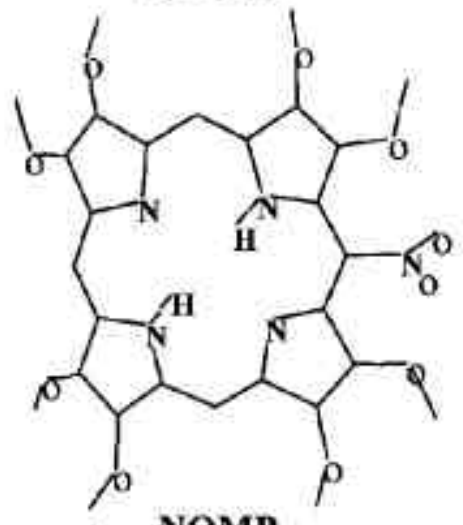

NOMP

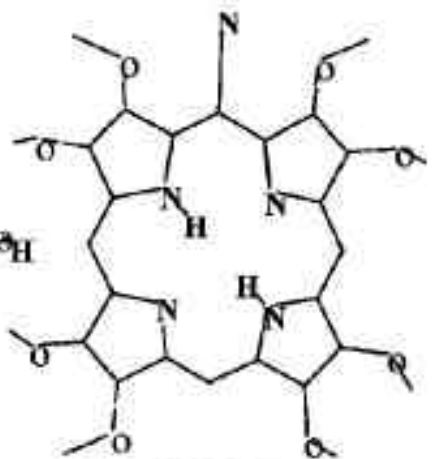

CNOMP

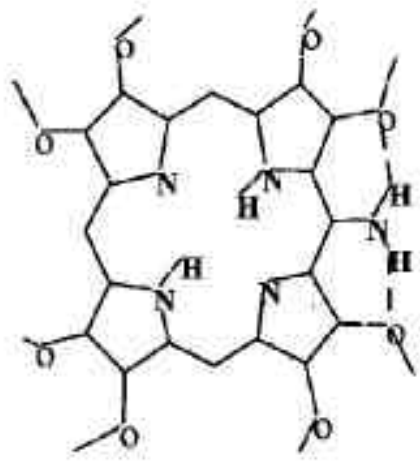

AOMP

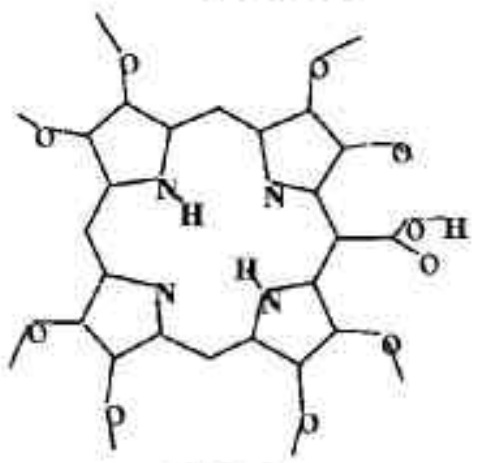

COMP

Figure 4. AM1 optimized structures of the free-base meso-substituted octamethoxyporphyrins (peripheral ring ' $\mathrm{H}$ 's are removed except for the substituents for clarity).

city in general (table 4). This is similar to those obtained for the aetioporpyrins and OEP. ${ }^{2 \mathrm{~b}, 16}$ In general, one $\mathrm{p} K_{a}$ value is observed for these porphyrins which has been denoted as $\mathrm{p} K_{4}$ by us. The second $\mathrm{p} K_{a}$ values of 3 at 7.85 was assigned to protonation of the $\mathrm{NH}_{2}$ functional group. The unexpectedly low basicity of these porphyrins is attributed to their rigid macrocyclic plane, which needs to be distorted in order to undergo protonation. This occurs at a higher acid strength, once deformed the monocation immediately undergoes protonation to form the diprotonated species, thereby making it difficult to separately determine the $\mathrm{p} K_{3}$ and $\mathrm{p} K_{4}$ from Henderson's plot.

AM1 calculations on the synthesized porphyrins have been useful in rationalizing the observed transition energies and $\mathrm{p} K$ values. The optimized structure of the mesosubstituted porphyrins is displayed in figure 4. Simple MO theory would ascribe the observed $B$ and $Q$ transitions to either $\left(a_{2 u} e_{g}\right)$ or 
Table 5. Calculated and experimentally observed transition energies for the meso-substituted octamethoxyporphyrins ${ }^{\text {a }}$

\begin{tabular}{|c|c|c|c|c|c|}
\hline \multirow[b]{2}{*}{ Porphyrins } & \multicolumn{4}{|c|}{ Q-bands $(\mathrm{nm})^{\mathrm{b}}$} & \multirow{2}{*}{$\begin{array}{c}B \text {-band }(\mathrm{nm})^{\mathrm{b}} \\
B_{x}(0,0)\end{array}$} \\
\hline & $Q_{x}(0,0)$ & $Q_{x}(0,1)$ & $Q_{y}(0,0)$ & $Q_{y}(0,1)$ & \\
\hline 1 & $\begin{array}{c}618 \cdot 0 \\
(526 \cdot 3)\end{array}$ & $\begin{array}{c}564 \cdot 0 \\
(415 \cdot 8)\end{array}$ & $\begin{array}{c}533 \cdot 0 \\
(366 \cdot 7)\end{array}$ & $\begin{array}{c}496 \cdot 0 \\
(353 \cdot 6)\end{array}$ & $\begin{array}{c}378 \cdot 0 \\
(322.9)\end{array}$ \\
\hline 2 & $\begin{array}{c}622 \cdot 0 \\
(522 \cdot 3)\end{array}$ & $\begin{array}{c}568 \cdot 0 \\
(406 \cdot 1)\end{array}$ & $\begin{array}{c}536 \cdot 0 \\
(368 \cdot 4)\end{array}$ & $\begin{array}{c}499 \cdot 5 \\
(360 \cdot 6)\end{array}$ & $\begin{array}{c}380 \cdot 2 \\
(323 \cdot 5)\end{array}$ \\
\hline 3 & $\begin{array}{c}643.6 \\
(579.9)\end{array}$ & $\begin{array}{c}587 \cdot 8 \\
(470 \cdot 5)\end{array}$ & $\begin{array}{c}552 \cdot 0 \\
(378 \cdot 2)\end{array}$ & $\begin{array}{c}515 \cdot 6 \\
(350 \cdot 8)\end{array}$ & $\begin{array}{c}409 \cdot 0 \\
(343 \cdot 2)\end{array}$ \\
\hline 4 & $\begin{array}{c}647 \cdot 4 \\
(532 \cdot 5)\end{array}$ & $\begin{array}{c}588 \cdot 4 \\
(424 \cdot 3)\end{array}$ & $\begin{array}{c}556 \cdot 4 \\
(371 \cdot 4)\end{array}$ & $\begin{array}{c}518 \cdot 4 \\
(366 \cdot 0)\end{array}$ & $\begin{array}{c}415 \cdot 0 \\
(344 \cdot 5)\end{array}$ \\
\hline 5 & $\begin{array}{c}622 \cdot 0 \\
(527 \cdot 5)\end{array}$ & $\begin{array}{c}568 \cdot 0 \\
(410 \cdot 3)\end{array}$ & $\begin{array}{c}536 \cdot 0 \\
(368 \cdot 0)\end{array}$ & $\begin{array}{c}499 \cdot 5 \\
(355 \cdot 3)\end{array}$ & $\begin{array}{c}382 \cdot 0 \\
(325 \cdot 7)\end{array}$ \\
\hline 6 & $\begin{array}{c}624 \cdot 0 \\
(532 \cdot 5)\end{array}$ & $\begin{array}{c}569 \cdot 5 \\
(419 \cdot 5)\end{array}$ & $\begin{array}{c}537 \cdot 5 \\
(367 \cdot 6)\end{array}$ & $\begin{array}{c}501 \cdot 0 \\
(352 \cdot 7)\end{array}$ & $\begin{array}{c}384 \cdot 6 \\
(327 \cdot 3)\end{array}$ \\
\hline 7 & $\begin{array}{c}623 \cdot 0 \\
(528 \cdot 2)\end{array}$ & $\begin{array}{c}569 \cdot 0 \\
(417 \cdot 1)\end{array}$ & $\begin{array}{c}536 \cdot 5 \\
(366 \cdot 2)\end{array}$ & $\begin{array}{c}500 \cdot 5 \\
(353 \cdot 8)\end{array}$ & $\begin{array}{c}384 \cdot 0 \\
(322 \cdot 1)\end{array}$ \\
\hline 8 & $\begin{array}{c}635 \cdot 5 \\
(524 \cdot 0)\end{array}$ & $\begin{array}{c}579 \cdot 5 \\
(411 \cdot 0)\end{array}$ & $\begin{array}{c}548 \cdot 0 \\
(368 \cdot 3)\end{array}$ & $\begin{array}{c}509 \cdot 5 \\
(360 \cdot 5)\end{array}$ & $\begin{array}{c}388 \cdot 4 \\
(330 \cdot 3)\end{array}$ \\
\hline 9 & $\begin{array}{c}620 \cdot 5 \\
(522 \cdot 3)\end{array}$ & $\begin{array}{c}566 \cdot 5 \\
(397 \cdot 4)\end{array}$ & $\begin{array}{c}535 \cdot 0 \\
(370 \cdot 1)\end{array}$ & $\begin{array}{c}498 \cdot 0 \\
(366 \cdot 5)\end{array}$ & $\begin{array}{c}381 \cdot 2 \\
(323 \cdot 5)\end{array}$ \\
\hline
\end{tabular}

${ }^{a}$ Figures in parentheses refer to the AM1 transition energies; ${ }^{b}$ absorption spectra were measured in dichloromethane at $298 \mathrm{~K}$

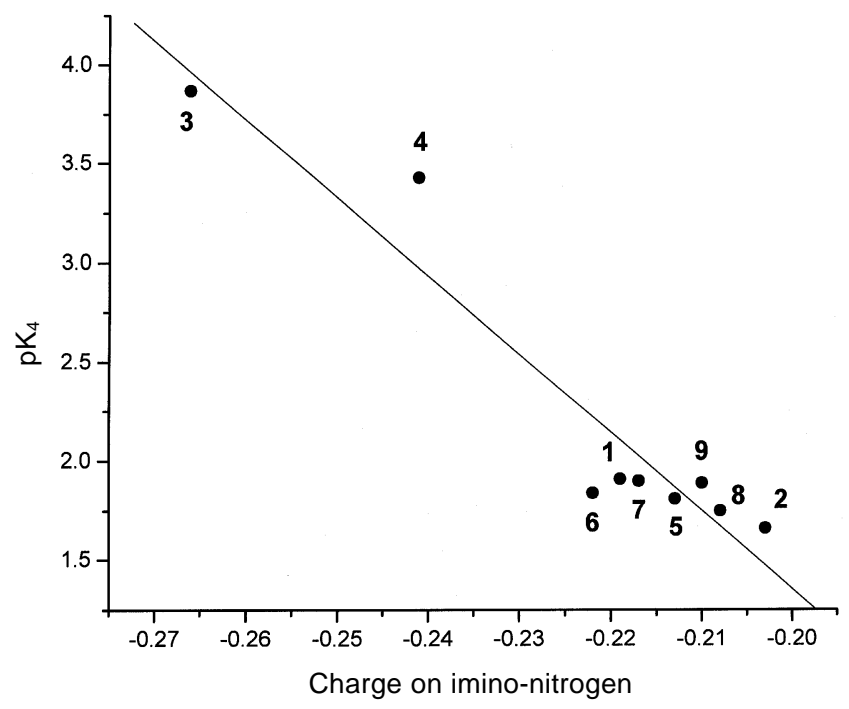

Figure 5. Plot of $\mathrm{p} K_{4}$ vs $\mathrm{AM} 1$ calculated imino nitrogen charge for the free-base meso-substituted octamethoxyporphyrins.

$\left(a_{1 u} e_{g}\right)$ configurations. However, if there is configuration interaction, the $Q$ and $B$ transitions must each be a mixture of such configurations. The excited states of porphyrin are viewed as arising from two configurations which can be mixed to varying degrees. It is found that all excited states are heavily mixed due to configuration interaction but this is restricted to the four orbitals (HOMO-1, HOMO, LUMO, LUMO+1) for the low lying $S_{1}$ and $S_{2}$ singlet states in the meso-substituted porphyrins, which supports the validity of Gouterman's FOM in predicting the qualitative spectra of porphyrins. The theoretically calculated transition energies faithfully reproduce the experimental trends in energies (table 5).

Several physico-chemical properties can be correlated to the theoretically estimated energy levels and electron densities at different atoms of these porphyrins. It has been possible to relate the average electron densities at the four nitrogens to the $\mathrm{p} K_{a}$ values. The lowering of the $\mathrm{p} K_{a}$ value with the decrease in charge density of the inner nitrogens in the series phlorin-porphyrin-chlorin-bacteriochlorin has been rationalized in terms of disruption of $\pi$-conjugation resulting in the non-planar conformation of the macrocycle. In general, an electron-donating 
group at the periphery of the macrocycle tends to increase the basicity of the nitrogens in the free-base porphyrin, while a decrease is expected for an electron-withdrawing substituent. This is reflected in the electronic charge on the imino nitrogens. Experimentally determined protonation constants $\left(\mathrm{p} K_{\mathrm{a}}\right)$ versus the computed charge densities on the imino nitrogens from AM1 calculations are plotted (figure 5). Experimental $\mathrm{p} K_{4}$ values correlate quite well (within experimental error) with the computed nitrogen basicities.

\section{Conclusion}

A new series of nonasubstituted porphyrins in which one of the meso positions was functionalized with various substituents has been synthesized and characterized. These porphyrins, in general, show weak basicity in spite of the presence of eight electrondonating methoxy groups at the $\beta$-pyrrolic positions. Crystal structure of meso-cyanooctamethoxyporphyrin reveals a planar core with strongly conjugated cyano group. Meso-functionalization of the octamethoxyporphyrin results in the red shift of all the $Q$ bands of the porphyrin and the magnitude of the red shift is fairly independent of the nature of the substituent. The trend in optical transition energies correlates well with the trend in the calculated values using the semi-empirical AM1 approximation method. UVVis spectra indicate red shift in the transitions of all the porphyrins irrespective of the nature of the substituents. Experimental data were well supported by AM1 calculated data.

\section{Acknowledgements}

The authors thank the Department of Science and Technology, Government of India for support. Thanks are due to Professor S Natarajan, JNCASR, Bangalore for the crystallographic data collection. PKP thanks the Council of Scientific and Industrial Research, New Delhi for financial support.

\section{References}

1. Kadish K M, Smith K M and Guilard R 1999 The porphyrin handbook (New York: Academic Press) vol. 4 and 6

2. (a) Johnson A W and Oldfield D 1966 J. Chem. Soc. (C) 794; (b) Sheela Rao and Krishnan V 1994 J. Mol. Struct. 327279

3. (a) Smith K M, Barnett G H, Evans B and Martynenko Z 1979 J. Am Chem. Soc. 101 5953; (b) Callot H J, Louati A and Gross M 1980 Tetrahedron. Lett. 21 3281; (c) Wu G-W and Leung H-K 1990 Tetrahedron 46 3233; (d) Wu G-W and Leung H-K 1990 Tetrahedron 463457

4. (a) Merz A, Schropp R and Lex J 1993 Angew. Chem., Int. Ed. Engl. 32 291; (b) Merz A, Schropp R and Dotterl E 1995 Synthesis 795

5. Falk J E 1964 Porphyrin and metalloporphyrins (Amsterdam: Elsevier)

6. Dewar M J S, Zoebsich E G, Healy E F and Stewart J J P MOPAC, Quantum Chemistry Program Package No. 455

7. Sheldrick G M 1997 Program for crystal structure determination, University of Goettingen, Germany

8. Baldwin J E, Crossley M J and DeBernardis J 1982 Tetrahedron 38685

9. Hombrecher K H, Gherdan V M, Ohm S, Cavaleiro J A S, Graca M, Naves P M S and Condesso M de F 1993 Tetrahedron 493569

10. Giumanini A G, Chiavari G, Musiani M M and Rossi P 1980 Synthesis 743

11. Smith K M and Bisset M F 1981 J. Chem. Soc., Perkin Trans. 12625

12. Vogel's textbook of practical organic chemistry 1989 5th edn, revised by B S Furniss, A J Hannaford, P W G Smith and A R Tatchell (London: ELBS/Longman) p. 1272

13. Abraham R J, Jackson A H, Kenner G W and Warburton D 1963 J. Chem. Soc. 853

14. (a) Bonnett R and Stephenson G F 1965 J. Org. Chem. 30 2791; (b) Inhoffen H H, Fuhrhop J H, Voight $\mathrm{H}$ and Brockmann Jr H 1966 Ann. Chem. 695133

15. (a) Gouterman M, Wagniere H and Snydar L C 1963 J. Mol. Spectrosc. 11 108; (b) Holten D and Gouterman M 1985 In Optical properties and structure of tetrapyrroles (eds) $\mathrm{G}$ Blauer and $\mathrm{H}$ Sund (Berlin: de Gruyter) p. 64

16. Grigg R, Hamilton R J, Jozefowicz M L, Rochester C H, Terrell R J and Wickwar H J 1973 J. Chem. Soc., Perkin Trans. 2407 